\author{
Robert Thorp \\ Uppsala University \\ Monika Vinterek \\ Dalarna University
}

DOI: http://dx.doi.org/10.5617/adno.8379

\title{
Controversially uncontroversial? Swedish pre-service history teachers' relations to their national pasts
}

\begin{abstract}
This article presents a study of how Swedish pre-service history teachers narrated their nation's past. Previous research on national history education has generally focused on the treatment of conflicts in national history and what challenges that poses for history education. The present study seeks to complement and broaden this research through its focus on a country where national history is generally perceived as uncontroversial and the debate on national history is generally characterised by consensus, and on what strategies future history teachers use when recounting the national history of Sweden. Using a qualitative approach, we asked our respondents to "Tell us the history of Sweden in your own words" in writing. The study finds that the vast majority of the respondents approach their national history in a way that reinforces a traditional view of Swedish national history. These narratives are generally presented in a way that does not engage with or show how perspective and position affects our rendering of history, which has often been regarded as problematic in history educational research. At the same time, these results also show that our respondents are well familiar with the dominant way of perceiving the Swedish past, something that could also be argued to be valuable in history education, depending on how we choose to approach national history.
\end{abstract}

Keywords: national history, history education, historical consciousness, uses of history

\section{Kontroversiellt okontroversiellt? Om svenska historielärarstudenters relation till deras nationella förflutna}

\begin{abstract}
Sammandrag
Artikeln presenterar en studie av hur svenska historielärarstudenter skildrade Sveriges historia. Tidigare forskning om nationell historieundervisning har främst närmat sig ämnet från ett konfliktperspektiv och undersökt vilka utmaningar detta innebär för historieundervisningen. Föreliggande studie söker att komplementera tidigare forskning genom att fokusera på ett land vars nationella historia generellt uppfattas som okontroversiell och där debatten om den nationella historieskrivningen i stor utsträckning präglas av konsensus, samt på vilka strategier historielärarstudenter använder när de skildrar Sveriges historia. Genom en kvalitativ forskningsansats bad vi våra respondenter att skriftligen”Berätta Sveriges historia med dina egna ord”. Studien visar att
\end{abstract}


majoriteten av respondenterna skildrar den svenska historien på ett sätt som återger en traditionell syn på Sveriges historia. Dessa narrativ är generellt skrivna på ett sådant sätt att de inte visar hur perspektiv och positionering påverkar hur vi skildrar det förflutna, något som ofta ansetts vara problematiskt i historiedidaktisk forskning. Samtidigt visar studiens resultat att respondenterna är välbekanta med det dominerande sättet att skildra den svenska historien, något som även kan vara värdefullt för historieundervisningen, beroende på hur vi väljer att närma oss den nationella historien.

Nyckelord: nationell historia, historiedidaktik, historiemedvetande, historiebruk

\section{Introduction}

The articles in this special issue all deal with controversial issues in social studies education. In history educational research, national history has often been portrayed as a particularly contentious issue that can spark controversies and reveal problematic topics in national history cultures (cf. Carretero, Rodríguez-Moneo, \& Asensio, 2012). It has furthermore been shown in research how national history not only relates to how citizens in nations regard their national context, but also to deeply rooted existential aspects of identity construction (Goldberg, 2017; Lévesque, 2017; Porat, 2004). In conflict-laden societies where national history is explicitly controversial, research has shown the need to focus on cognitive aspects of history education in order to defuse the conflicts that surround national history (cf. Bentrovato, Korostelina, \& Schulze, 2016). We do, however, know less about national history education in societies that do not have explicit societal conflicts regarding the national past, but instead are characterised by a consensus. Sweden has been shown to be such a country (cf. Olofsson, Samuelsson, Stolare, \& Wendell, 2017; Persson, 2016; Samuelsson, 2017; Vinterek, Donnelly, \& Thorp, 2017), and in this article we are interested in how 36 Swedish pre-service history teachers narrated and approached Swedish national history. Do they present a national history devoid of conflicts and how do they position themselves in relation to this national history?

From a Swedish perspective, history education has a close relationship to national history. Historically, the teaching of history was seen as crucial in promoting the nation state, and history education generally meant national history education (cf. Andolf, 1972). Through good moral examples from the history of their country, school children were supposed to get a sense of pride in their nation and build a strong moral character (Spjut, 2018). This trend has also been corroborated by international research; national history was predominantly a matter of disseminating a narrative of the state or nation and to tell of the hardships and successes of this same state (Carretero et al., 2012). Conflicts were not necessarily regarded as something negative, but could instead be regarded as examples showing the moral depravity of the enemies, or moral superiority of the own nation. In this sense, history education could be seen as instrumental in the 
creation of national identities among its citizens, but also of othering of perceived enemies to these states. As such, history education can be argued to have a strong focus on morally normative issues: through studying history, children will learn what is necessary to become good citizens, i.e., history education will provide them with good moral examples to follow (cf. Alvén, 2017).

This approach to history education and national history was increasingly seen as problematic after the two world wars, and the national and nationalist perspective in history education was perceived as particularly troublesome (Åström Elmersjö, 2013). Instead of fostering a sense of national pride and moral character, the argument now was that history education should instead focus on global perspectives, consensus rather than conflict in history, and a fostering of disciplinary skills among history students (Nygren, 2011). Gone was the ideal of mono-perspectival renderings of the national past, and instead history education was focused on global and inclusive perspectives as well as the disciplinary practices of historians. Through studying the past and learning historiographical techniques, students were supposed to become more knowledgeable, tolerant and autonomous. Thus, history education has seen a transformation regarding the content of what should be taught, but still plays a normative role.

Research on the teaching of national history has recently been mostly devoted to how history educators may approach national histories in societies in which it is contested (e.g., Ahonen, 2014; Bentrovato et al., 2016; Chinnery, 2019; Åström Elmersjö, Clark, \& Vinterek, 2017), i.e., researchers have explicitly focused on national contexts where national history education is controversial and thus educationally problematic. A key aspect here has been to focus on the disciplinary aspects of history as a way of reaching a consensus between conflicting narratives. Sweden presents a different case where national history generally is regarded with consensus instead of being a source of dispute (e.g., Danielsson Malmros, 2012; Olofsson et al., 2017; Samuelsson, 2017; Zander, 2001), even though, of course, Swedish history does contain topics that are challenging and could be approached from conflicting perspectives (e.g., Alvén, 2017; Indzic Dujso, 2015; Linderborg, 2001; Lindmark \& Sundström, 2017; Lozic, 2010; Nolgård \& Nygren, 2019; Runcis, 1998). While we have knowledge and an academic discussion of how conflict-ridden societies approach their national history in history education, we know less about how national history is approached in societies with a low degree of conflict regarding its national past and what challenges, if any, that may pose to history education. We believe that a good starting point for learning more about this would be to glean how future history teachers perceive Swedish national history and how they position themselves in relation to it.

Thus, the present study seeks to engage with the topic at hand from three different but interconnected perspectives: (i) what national history is presented by the pre-service teachers?; (ii) how do the pre-service teachers approach the national history they present?; and (iii) what implications may these results have for history education? Drawing on these results, we engage in a discussion of the 
importance of fostering an awareness of the narratological and representational aspects of how national history is approached and disseminated in history education.

\section{Research context}

A strong trend in current research on history education stresses the importance of a disciplinary approach to the subject. As one example among many, the highly influential Canadian researcher Peter Seixas argues that traditional history education geared towards the transmission of a single best narrative is problematic, due to its tendency to approach history as one simple narrative of the past aimed at creating social cohesion. Instead, he claims that history education should focus on disseminating skills and tools that will enable students to critically scrutinise historical narratives and to inquire how they were constructed (Seixas, 2000). Seixas envisages history education as "[a disciplinary] exercise in history [as] an objective, disinterested investigation" (Seixas, 2000, p. 24). One central idea here is that students who are submitted to this kind of history education would be less prone to be swayed by propaganda or political uses of the past. This approach to history education can be perceived as aligned with the push away from the exclusive nationalist history education of the past, to the more inclusive global disciplinary ideal of modern history education. If we relate this to national history education, we can argue that an aim here seems to be that what students should learn in history education, primarily, is not to be proud of their nations, but rather to be able to approach these national narratives with distance and caution and deconstruct them.

Still, recent research has shown that history students (and others) tend to rely on what could be perceived as rather traditional renderings of the past, in particular when it comes to the national past (e.g., Angier, 2017; Goldberg, 2017; Vinterek et al., 2017). Canadian researcher Stéphane Lévesque argues that national histories and narratives are particularly salient to how we construct identities and make sense of ourselves and the world around us. Being a member of a nation means that you identify yourself with that nation, and here history plays an important role (Lévesque, 2017). This view is accentuated by Israeli researcher Tsafrir Goldberg who studied how Palestinian and Israeli adolescents mobilised history in discussions among each other. Even though the informants were provided with textbook accounts and source material of their national past, they chose to rely on personal and more traditional historical accounts since they resonated with their personal beliefs and opinions of their national pasts (Goldberg, 2017). These results seem to suggest that national history goes well beyond being a topic that is suitable for an objective disinterested exercise in history, but rather relates strongly to deeply seated aspects of identity and citizenhood. In this sense, national history becomes a highly normative, and 
potentially heated, subject that can evoke strong feelings of sympathy or antipathy among students of history.

As already noted above, research on national history and history education tends to focus on countries or societies where there is a tension or a conflict regarding the national past. Studies in Australia (Macintyre \& Clark, 2004), Canada (Létourneau \& Chapman, 2017; Lévesque, 2017), South Africa (Angier, 2017; Wassermann \& Bentrovato, 2018), Spain (Serrano \& Lopéz Facal, 2016), Finland (Löfström, 2012), Israel (Goldberg, 2017; Porat, 2004), and BosniaHerzegovina (Ahonen, 2014), providing some excellent examples, all show how history plays an important but also problematic role in framing and solving these controversies. In order to solve the national controversies in these societies, the general consensus among this research seems to be a move towards a national history education that enables students to meet multiple perspectives on the past and to destabilise and deconstruct their own favoured national narratives. Stéphane Lévesque writes that:

Any sound approach to helping students develop this competence must give them not a preferred national narrative to orient their lives (which is traditionally the role of collective memory), but the scholastic opportunities and tools for making sense of multiple narratives of the nation. Students must come to understand and appreciate that there are diverse, and possibly contradictory, narratives of the collective past that coexist within a national historical culture. Students' own stories must ultimately be 'polythetic and admit alternative narratives’ [...]. (Lévesque, 2017, p. 238)

Thus, the gist of this argument is that national narratives, if left alone, can be potentially dangerous due to their propensity to exclude other legitimate perspectives on the national past and, consequently, render students (and others) intolerant towards other competing perspectives on the national past. The solution here is to provide pre-service history teachers with alternative narratives of their national past and to equip them with the disciplinary skills necessary to destabilise and deconstruct their own narratives of their national history. This, however, may prove to be a rather daunting task, given the challenges emphasised earlier.

As previously mentioned, the context of Swedish national history differs from those highlighted in the research above in the sense that it generally is perceived as being characterised by consensus. Swedish researcher Johan Samuelsson noted that the most heated debate in recent years in Sweden was whether to include the history of Ancient Greece and Medieval Europe in the Swedish history syllabus. He shows that the focus of the public debate about Swedish history education was about how it could serve the purpose of creating national cohesion and identity (Samuelsson, 2017). A recent survey of how adolescents and adults perceived Swedish history (Olofsson et al., 2017) revealed that Swedish national history culture seems rather homogenous and focuses on disseminating a view of Sweden as a country that used to be plagued by war and poverty, but has now become a prosperous democratic welfare state. This is in line with what can be perceived as 
the grand narrative of Swedish history. This view has been corroborated by other research (e.g., Danielsson Malmros, 2012; Zander, 2001).

Research on pre-service history teachers tend to show that they are oriented towards content related aspects of history, and have difficulties grasping the disciplinary aspects of history education (e.g., Akinoglu, 2009; Lilliestam, 2015; Ludvigsson, 2011; Serrano \& Lopéz Facal, 2016; VanSledright \& Reddy, 2014; Wansink, Akkerman, Vermunt, Haenen, \& Wubbels, 2017). This is generally perceived as problematic since these prospective history teachers will then be more likely to teach the substantive or content related aspects of the subject rather than the disciplinary ones that could be used for a critical approach to history and historical narratives.

Taken together, we can say that recent research on history education and national history promotes a more disciplinary approach to history education, instead of the traditional renderings of historical narratives. This is perceived to be particularly pertinent in relation to national history since it is an historical topic that is quite likely to resonate with students (and teachers) on a more personal level because it is an integrated part of our identities. In societies where there are controversies regarding national history, this may prove to be a contentious task and history teachers face the task of trying to diffuse or destabilise various national history narratives they may encounter. The Swedish situation is different. Instead, there is a generally positive consensus regarding the nation's past.

\section{Historical consciousness, historicity and uses of history}

The theoretical approach that we have taken in this study centres on the concept of historical consciousness as a descriptive, normative and analytical history educational concept. A key aspect regarding history and history education is how history is a reconstruction of past events: the past has left us with traces that we use to construct historical narratives (Parkes, 2011). These reconstructions are always carried out in time and space and they are therefore contingent on this historicity (Gadamer, 1975). Furthermore, whenever we approach the past or history, we do so from a particular perspective. Taken together, this means that history and historical narratives are always contextually contingent. To be aware of this historicity is to display an historical consciousness (Jeismann, 1979; Thorp, 2016). If we relate this to how we may approach history, we can say that an historical consciousness will enable the individual to approach history and historical narratives as contextually contingent constructions that rely on the time, place and perspective from which they were constructed, i.e., they are contingent on the history culture they were constructed within and the uses of history they portray. Another crucial aspect of historical consciousness is that it not only asks us to direct our attention towards the historical narratives we encounter, but also to how we encounter these narratives, i.e., to the history cultures that we are members of 
and the uses of history we make when approaching history. Thus, historical consciousness pushes us to engage with the complexity of history not only from a genealogical, but also from a genetic perspective (cf. Karlsson, 2014). Since historical consciousness is an abstract concept centred on the epistemic dispositions of individuals, it is only implicitly accessible through the uses of history individuals make (Thorp, 2016).

Uses of history can be understood as the narrative enactments of the past that we make whenever we use history to convey something (Nordgren, 2016; Thorp, 2015). With this view, history is always infused with uses of history and whenever we approach history we also apply uses of history to it. Since the theoretical perspective taken here focuses on the narrative properties of history and how we epistemically engage with these narratives, we have chosen to focus on three narratological dimensions of uses of history using a modified typology of historical narratives developed by German philosopher of history Jörn Rüsen (2012): a traditional narratological use of history where history is presented as static and a-contextual, a critical narratological use of history where history is used to destabilise or criticise historical narratives, and a genetic narratological use of history where history is portrayed as dynamic, contextually contingent and characterised by both continuity and change (Thorp, 2017). If we connect this to historical consciousness, we can say that a certain narratological use of history corresponds with how an individual epistemically engages with historical narratives (Thorp, 2016). An individual who uses history genetically, engages with the historicity of both the historical account at hand and her own meaning-making in relation to that historical account. An individual who uses history critically, engages with the historicity of the historical account at hand, but not with her own meaning-making in relation to that account. Finally, an individual who makes a traditional use of history, neither engages with the historicity of the historical narrative at hand, nor with her own meaning-making. Thus, we can argue that a certain narratological use of history may indicate how an individual views history epistemically, and that a genetic use of history indicates an awareness of historicity, i.e. historical consciousness, while a traditional use of history does not indicate such awareness. In the context of our study, this theoretical perspective enables us to analyse how our respondents approach national historical narratives they present, both regarding content and how they engage with the historicity of these narratives and their own approaches to the task at hand.

\section{Methodology}

Since we were interested in gleaning what national narratives history teacher students in Sweden have at hand, we decided to use an open-ended narrative methodology inspired by Canadian researcher Jocelyn Létourneau (2008). This research design is intended not to test respondents' knowledge of history, but 
rather to enable analyses of the history they have close at hand and how they chose to narrate and position themselves in relation to that history, i.e., what can be argued to be their internalised notions of history. While we were interested in how our respondents would narrate Sweden's national history, we chose to avoid the term 'nation' in the cues they were given (due to the connotations the term might have), and instead we instructed our respondents to "Please tell us about the history of Sweden in your own words". It should also be noted that we have chosen to approach the term 'narrative' rather loosely, and in the context of this study it should be regarded as the written answers our respondents provided. This open-ended research design allowed our respondents to approach the assignment in any way they seemed fit: they could choose to present us with a narrative focusing on the content of Swedish history, but they could also choose to engage with the task at hand from a more critical and disciplinary perspective. The key aspect here is that we would get data on what they perceived to be an appropriate way to complete the assignment they were given.

\section{Respondents and data collection}

The respondents of this study were pre-service history teachers from three universities in Sweden who all had history as their main teaching subject. The respondents had studied history for at least 6 months at a Swedish university. They were given 45 minutes to complete an online survey asking them to tell the history of Sweden in their own words. They were asked not to access the internet, as we were interested in accessing the national narratives they had close at hand, rather than a 'correct' rendering of Sweden's history. All of the respondents were monitored while completing the online survey. Each respondent was informed of the research project, that it was voluntary to participate, and that the data they provided would be used for scientific purposes. All respondents consented to participate in the research project, and all of them were anonymised. In total, 45 pre-service teachers participated, but 9 answers were incomplete and are therefore not included in this study. This leaves us with a total of 36 narratives. These narratives varied in length from 159 to 882 words, with an average of 498 words. All of the quotations presented here were translated from Swedish to English by the first author of this article.

\section{Analysis of data}

When analysing the data, we focused particularly on three aspects: (i) narrative form (i.e., chronological, thematic, et cetera), (ii) agency and positioning (i.e., what agents are found in the narrative, and how do the respondents position themselves in relation to the narrative), and (iii) narratological uses of history (i.e., to what extent do they indicate an awareness of historicity). Regarding narrative form, we chose to code a reply that narrated Swedish history prospectively (starting from a point in time and then proceeding to another one) as chronological. The replies that were coded as thematic narrated Swedish history through 
the lens of a certain theme, e.g., gender, human rights, et cetera. When coding agency and positioning, we analysed what agents we could find in the replies (e.g., historical persons, the Swedish nation or the respondent him- or herself). Here we further analysed what narrative voice the respondents applied: did they apply a zero-perspective where there is no explicit sender in the narrative, or a perspective where there is an explicit sender, be it the respondents themselves or someone else. After repeated readings and individual coding, our individual codings were compared and in the rare instances where we disagreed, we managed to reach an agreement after discussion.

\section{Results}

\section{Narrative form}

When we look at narrative form, we can see that the chronological narrative order is dominant in our data-set: 20 of the narratives we analysed were chronological, 8 were coded as thematic, and 8 were coded as 'other' since they were either too short or incoherent to analyse. The chronological narratives gave prospective accounts of Swedish history, starting at some point in history and then moving forward. Two typical examples are presented here:

During the Napoleonic wars, Sweden stood on both sides, but when Jean-Baptiste Bernadotte, one of Napoleon's greatest generals, was offered the Swedish throne, Sweden's position in the North was strengthened and Sweden fought on the side of the alliance against Napoleon at the battle of Leipzig. The Swedes had hoped that Bernadotte would reclaim Finland that was lost in 1809 to Russia, but after Leipzig he decided to take Norway from Denmark instead. Norway was forced into a union with Sweden. This union only lasted a hundred years, however. Since then Sweden has always taken a rather neutral position in international conflicts, and if we disregard that Swedish railway and communication networks were used by the Germans during World War II, Sweden has stayed out of the big conflicts. Sweden continues to wage a policy of neutrality in the world to this day. (Respondent 16)

During the Middle Ages (500-1500?), Sweden was an agricultural society, and it would remain so for a long time. There was no central power, but instead the country was divided into 'clan-kingdoms'. Some of these went plundering across the seas - the Vikings. The Vikings [...] travelled by ship and financed their journeys through plundering villages and merchants. It was a way of life that many today would associate with brutality and violence. [...] With Gustav Vasa the Swedish kingdom is united for the first time in 1522 and the Middle Ages are transformed into some kind of Swedish renaissance. The centuries before had been devoted to a struggle for power between different clans. But with Gustav Vasa we get a codified national law. (Respondent 42)

These excerpts, taken from longer narratives, offer accounts that are typical in many ways of the chronological approach. We learn about the transition of a historical period that in certain ways offer some kind of resolution to earlier problems. From the example of Bernadotte we learn that Sweden has stayed out 
of war for a long time and we get to know that Gustav Vasa brought unity to a country that used to be ruled by different clans and was characterised by "violence and brutality". Another aspect of the chronological narratives above is that they seem to impose what could be called a narratological distance between the narrator and the narrative. We are presented with narratives that are quite matterof-factual; we get a glimpse of how it used to be. These narratives are written from what can be called a zero-perspective since there is no narrative voice, but rather an impersonal account of Sweden's past. Taken together, these characteristics tend to support the conclusion that what we are dealing with here are grand narratives of Swedish history that deflate a historical reconstruction of the past with the past itself (cf. Ankersmit, 2013; Lyotard, 1984). Perhaps this may be due to the chronological form itself since it more or less pushes the narrator into creating a coherent narrative that proceeds logically from one point in time to another. This may be quite hard to do (in a limited amount of time) without imposing one particular perspective on the past. Furthermore, this narrative voice is also what could more or less be perceived as the default mode of historical representation (particularly in history education), and is thus a dominant way of disseminating history (cf. Thorp, 2015).

If we look at the thematic narratives, we get a rather different approach to constructing a narrative of Swedish history. Below is one example that we coded as thematic:

Sweden's struggle for labour movement rights and the female struggle of the $19^{\text {th }}$ century and in the beginning of the $20^{\text {th }}$ century are also important to me in my history of Sweden. The shootings at Ådalen to me marks the end of something that changes our political direction. When we got female suffrage in 1921, it became the starting point of something new in our history. The political history of Sweden is of course filled with battles and different ideological motives, and this has mirrored our history. (Respondent 44)

This excerpt from a longer account gives a heavily condensed version of the political history of Sweden in the $19^{\text {th }}$ and early $20^{\text {th }}$ centuries. One striking difference from the chronological narratives above is that we have a pertinent sender here. The respondent uses the first person pronoun when constructing the narrative and we can see that he or she is more present in the narrative and takes an active role in constructing the narrative. This may be due to the thematic form of the narrative since it requires the narrator to construct a narrative that fits the theme at hand. Instead of being controlled by the logic of the chronological narrative form, the respondent has to actively choose which theme to present and then to convey historical events that correspond to that theme. This also seemed to have relevance to how agency and positioning was constructed in the analysed narratives. 


\section{Agency and positioning}

Regarding how the respondents created agency and positioning in the narratives, there are a few characteristic approaches. The first of these takes a neutral approach to agency and positioning:

Before Sweden became a united kingdom, warlords fought for local dominance in the southern and central parts of Sweden. Eventually, these people developed weapons, tools and seafaring skills [which transformed] us into itinerant traders and plunderers. The Vikings ravaged large parts of Northern Europe, but also penetrated deep into modern day Russia and Persia. They were feared for their metalworking skills and managed to develop flexible steel that was much more advanced than what you could find in other places. Sweden was christened by the Catholic church during this period. (Respondent 26)

In this excerpt that accounts for Sweden's early history, the respondent uses the third person voice throughout (if we disregard the 'us' on the third line of the quotation). This narrative strategy produces a kind of distance to the narrative and creates an impersonal account of the events at hand given from the zeroperspective. As with the chronological narrative form above, this works to give the account a factual character, i.e., the impression we get is that this is an account of what really occurred in the past and as such it indicates a grand narrative approach to Swedish history. Another similar approach also used by several respondents along with the chronological narrative form, is to grant agency to the Swedish nation:

Sweden stayed neutral during both world wars, even if some of its actions during the wars can make us question this neutrality. Women [...] started to get more rights in society during the $19^{\text {th }}$ and $20^{\text {th }}$ centuries. Industrialisation came to Sweden in the 1850 's and Sweden could create job opportunities for its people through forestry and the ore that it is rich of. [...] Sweden could furthermore refine its natural resources since mass education had increased the number of literates and intellectuals in society. (Respondent 4)

As with the previous quotation, this approach serves to produce a narratological distance since, even though we have an historical agent here, this agent is the nation itself. In one sense, this approach may indicate an even stronger zeroperspective since what has happened in Swedish history is not the cause of individuals' choices or struggles between different groups in society, but instead something that the Swedish nation does for the people who inhabit it. This conflation of historical agents and events with the nation itself gives the narrative a strong deterministic character, and thus Swedish history may be perceived as being entirely teleological in nature. Once again, this indicates a strong alignment to a grand narrative of Swedish history. A third approach that is commonly used by the respondents along with the chronological narrative form, is to use the inclusive 'we': 
One example is that we had certain geographic advantages since we had a long coastline, fertile soils and an abundance of natural resources such as wood and iron. From an EastWest perspective, we had access to both the Baltic Sea and the Atlantic Ocean. In the South there were several canals that easily transported us on the European and Central Asian continent. We were saved from the ravages of the Mongolians and could because of our geographical position strike deals with other great powers between the $15^{\text {th }}$ and $21^{\text {st }}$ centuries. (Respondent 40)

As we can see in the quotation above, the use of the first person plural pronoun marks proximity to Swedish history in a way that the previous quotations do not. Here we as Swedish citizens play a more or less active part in the nation's past regarding the content of what has happened there. However, as with the other chronological narratives, from a historiographical perspective, Swedish history takes on the appearance of being something that is devoid of perspective, interpretation and reconstruction. Yet again we have an approach that indicates a strong alignment with a grand narrative of Swedish history.

As we have shown above, the thematic narrative form used by eight of our respondents, seemed to warrant a more active role on the part of the respondents. Here is one characteristic example:

If we are to highlight anything from Sweden's history, then it is the consensus and acceptance of changes without larger conflict. Sweden is leading when it comes to feminism and HBTQ-issues, and, even if we can always improve, these are sources of joy in our history. That we used to be an empire and had warrior kings is not the history I want to tell. Sweden as a country of peace with acceptance and human rights is what I would prefer to stress. Even if we can improve when it comes to the Sámi people and northern Sweden. (Respondent 11)

In this quotation, which is strikingly different from the others above, the respondent takes a very active role when disseminating Swedish history. Focusing on the theme of human rights issues, the respondent actively chooses not to include histories of kings and wars, but instead wants to show a more positive view on the nation's past, even if he or she thinks we could have done better on the part of our minorities. If the other approaches have an entirely prospective approach to narrating Swedish history, this approach instead applies a contemporary retrospective perspective on the past. There are certain values in present day society, e.g. human rights, that we can use history to promote, and, accordingly, the history of Sweden we should narrate is one that focuses on peace and human rights. As was noted above, this may be due to the thematic narrative form since it requires a more active reconstruction of Swedish history by the respondent. Another difference between this approach and the others above is that the respondent takes an actively critical stance on Swedish history, or, rather, common ways of disseminating Swedish history. The respondent makes an actively critical use of history, which leads us to the final aspect of our analyses: respondents' narratological uses of history. 


\section{Narratological uses of history}

Of our 36 narratives, 27 were coded as making traditional narratological uses of history, 6 were coded as making critical narratological uses of history, and 3 were coded as making genetic narratological uses of history. This means that the dominant use of history in our data-set was the traditional one. Here is one typical example of a traditional narratological use of history:

The first people living in Sweden were nomads or collectors, they stayed for as long as there was food in one place and then walked on to the next; they were careful never to completely empty the temporary place of food to make sure that new crops would grow. With the agricultural revolution, people became permanent residents, but to some extent they were still collectors for a long time. (Respondent 37)

This excerpt presents an account that may be hard to criticise regarding its content, but it does not engage with the historicity of historical representation and interpretation. Even though it recounts a distant past that is quite sketchy concerning the historical source material available to us, we get a rather straightforward and tidy account of how the transition from nomadism to permanent settlement happened. The result is that we get an account that recounts the Swedish past as static and a-contextual, and in this sense the narrative takes on the appearance of being stable and impervious to interpretation and perspective. Furthermore, there are no traces of the choices and active reconstruction on the part of the respondent. The traditional narratological uses of history seem to correspond to a great deal to the chronological narrative form and a grand narrative approach to Swedish history.

If we look at the critical narratological uses of history, we can see that these differ from the traditional in the sense that they seek to challenge or destabilise a certain historical perspective. Here are two typical examples:

With the help of a lot of luck we managed to avoid active participation in the two world wars during the 20th century, which would create a kind of neutrality mentality among Swedish people, which I among others regard with utter scepticism. Yes - we didn't fight actively, but Swedish governments definitely chose sides in the wars. (Respondent 24)

What we are bad at doing when we talk about Sweden's history, is to mention female persons such as queens and kings' mistresses. These are only mentioned in the background and men are always portrayed as most important. (Respondent 18)

Here we see that the respondents take a more active role in disseminating Swedish history, since their own opinions and choices are explicit in the text. The respondent behind the first quotation takes a stand against what is perceived to be a too unproblematised view of Swedish neutrality during the two world wars, and the second respondent reacts against the prominent position that is typically given to men in Swedish history. As such, these uses of history show that history is contingent on perspective and the respondents actively challenge what they 
perceive to be the grand narrative of Swedish history. They do not, however, seem to acknowledge that their own position is equally contingent on perspective and thus open to scrutiny. The counter-narratives that they impose are indeed legitimate and can serve to open up a discussion on the historicity of Swedish history in the broadest sense of the term, but the agenda here rather seems to be to offer a corrective to a flawed perception the Swedish past. Thus, the contextual contingency and historicity on the part of the respondent and narrator is not open for discussion.

There were three narratives that were coded as making genetic narratological uses of history, and as such they can be seen as rather exclusive. We take a closer look at each of these narratives, since they offer three different strategies in approaching the assignment at hand, that provide us with insights on how national history can be approached in a way that engages with historicity. The first of these narratives adopts what could be called a more narratological approach and engages with how we may perceive national narratives as such:

Sweden's history is stories of what has happened within and affected a specific geographic area. What we know from studying the sources available, storytelling traditions and archaeological material. First and foremost, the story of the people who lived, lived and worked here but also those who passed by, invaded and bargained in the communities that existed. Talking about 'Sweden's history' can be seen as a product of nationalism. National states limit areas and divide narratives into manageable entities, a division that can equally be done in other ways but still becomes necessary because it is in this way that people have separated 'we' from 'them' during the ages that are close enough for us to relate to.

Sweden's history is also the story of how a particular country and a specific culture has influenced other stories. And perhaps how they have thus influenced and influence others in a long chain that might lead to 'the Great Story'. A vast wilderness area in the periphery of human civilisation, on the verge of barbarism, which, in encounters with the European continent, began to be organised as a state based on religion and despotism. The story of a story, a narrative that is being built to describe, explain and justify what we call 'culture'. A story that can be seen in an infinite diversity of perspectives, oppressors and oppressed, liberators and occupiers, colonisers and the colonised. Perhaps all of these perspectives have merged into a story of who we are [as a] collective the people. The history of a country, with its determined laws, its collective consciousness and memory, people become part of it as soon as [we] interact with it. (Respondent 23)

What we have here is a complex and initiated discussion on how and why we form national narratives but also how these narratives may come to shape us and our perception of ourselves. The history of Sweden is the result of the work of historians, but this history also affects people and is in turn used to define who we are and to create a Swedish identity. As such, a national history is also a choice or merging of diverse perspectives that we may interact with in different ways. What we do not get with this approach is any kind of content of Swedish history, but still the respondent shows how we may approach national history in a way that 
indicates an awareness of historicity. The second genetic narratological use of history engages in a discussion of how we may perceive the notion of 'Sweden':

Sweden's history can be claimed to begin already during the Middle Ages, but it depends on how you categorise Sweden. Do we mean its people in a nationalistic perspective, or do we refer to the nation state, or, even more commonly, when the term 'Sweden' was used for the first time? The term 'Sweden' was probably used during the Middle Ages, but more as a geographical name for where the king had power. The idea that countries and nations are not directly linked to a people or a nation is widely accepted in research and is often used. It is first during the end of the $18^{\text {th }}$ and the beginning of the $19^{\text {th }}$ centuries that notions such as the nation state start to appear, as is the case with Sweden that before the advent of nationalism was synonymous with the symbol of the king [...] rather than the nation state. (Respondent 13)

Here the respondent shows us how the notion of Sweden is contextually contingent and dependent on from which perspective you approach Swedish history. In this discussion, the respondent manages to show that how we define Sweden is a matter of temporal perspective and that the modern notion of Sweden as synonymous with the Swedish nation state is a relatively recent phenomenon. Using this approach, we may engage in further discussions both regarding the historiographical origins of our perception of Sweden, and how our view of Sweden is contingent on which perspective we choose to approach it from. This in turn can serve to destabilise any narrative of the history of Sweden. The third genetic narratological use of history approaches the assignment from a more historiographical perspective:

Sweden's history generally starts in the $10^{\text {th }}$ century since the source material that exists before the $10^{\text {th }}$ century is archaeological and therefore difficult for historians to use. The sources that do exist from the beginning of the $10^{\text {th }}$ century are runestones and similar source material, and therefore it is more valuable to analyse the contemporary culture of [these sources] rather than the events [they depict]. Societal structures and cultural clashes with other foreign people from the Mediterranean and the Ottoman kingdom become more understandable and manageable for historians as we enter the $11^{\text {th }}$ century. It is the Viking Age that most commonly confirms our first historical era and that today provides us with a notion of Sweden as a country, and a wider picture including other countries and cultures. As a result of this, more source material is available and historians can compare views of 'Swedes' and what these mean. Furthermore, we can scrutinise how 'our' history is valued [not only] by us, but also from other perspectives. (Respondent 22)

This respondent engages in a discussion of how our perception of Swedish history is contingent on the source material from which it may be reconstructed. The farther back in history we go, the more uncertain and difficult the work of the historian is, because we do not have any written sources to work with. As we get more historical sources, historians can use these to engage in reconstruction of Swedish history and engage in analyses of how we have come to construct our views of Sweden. Once again, this approach may invite discussions of the 
historiographical origins of Swedish history and how and why we have the view of Sweden that we do have presently.

Taken together, these examples of genetic narratological uses of history provide examples of how we can approach national history in complex and multifaceted ways. This may in turn enable us to engage in complex discussions of both what histories we choose to tell about Sweden and how any history of Sweden inescapably is subject to historicity in the broadest sense of the term and thus contextually contingent regarding where the narrative comes from and how we may approach it.

\section{Concluding discussion}

These results seem to confirm what has already been established in previous research: pre-service history teachers are generally inclined to approach history from an uncritical and content-focused perspective. Furthermore, they generally tend to present a view of Swedish history that is characterised by a focus on traditional political history where we are presented with a picture of a Sweden that used to be poor and plagued by wars, but has now transformed into a modern welfare state that is economically prosperous. The overwhelming majority of the respondents narrated a history of Sweden that was closed and presented one seemingly neutral perspective on the nation's past. This may be cause for concern if we regard the disciplinary aspects of history education, since there are few examples of the disinterested objective investigation that Peter Seixas (2000) and others have convincingly argued for. We are neither presented with the polythetic and alternative narratives that Stéphane Lévesque (2017) thought instrumental in fostering a tolerant and democratic society. Instead, the majority of our respondents seem to indicate a strong alignment with dominant ways of perceiving the national past, similar to the results that Goldberg (2017) and Olofsson et al. (2017) have shown. Even though there are respondents who raise concerns about how Swedish history is usually narrated, they are few. And even fewer are those who engage in historiographical or disciplinary discussions of how we can and should narrate Swedish history and what significance that may have, even though that option was available in our research design.

These results could also be a symptom of the comparatively strong consensus of national history that characterises Swedish national history culture; Swedish history is rarely contested and the dominant agenda in Swedish history education is aimed at creating social cohesion and national identity, as Johan Samuelsson (2017) has shown. Viewed from that perspective, our results indicate that our respondents generally have a view and relationship to their national history that show social cohesion and a sense of national identity. Even if we have not shown it here, there were in all narratives slight variations to what could be seen as the grand narrative of Swedish national history. Thus, from a normative perspective, 
our results could indicate that we have future history teachers who are well prepared to deliver a national history education that will foster social cohesion and national identity. If this is at all desirable in history education could be contested, however, but to be able to participate in a modern democratic society it could be argued that you, along with an ability to critically assess information, need to be able to participate in social discourses on a wide variety of topics. One quite central topic is national history.

One aspect that was revealed by our results, was that how we approach national history narratologically seems to affect what kind of history we present. The few respondents who engaged with the historicity of the task at hand, gave very different accounts of their national past than those who did not. Furthermore, the form of the narrative seemed to generate certain kinds of narratives and the chronological narrative quite consistently generated accounts that were closed, mono-perspectival and applied traditional narratological uses of history, and thus controversially uncontroversial in the sense that they did indeed present one normalised grand narrative of the Swedish past. These results point towards the importance of fostering historical consciousness, i.e., an awareness of the historicity of the histories we present and how we approach them, as an important cognitive resource history teachers may use to be able to engage with the cultural aspects of how we approach national history. This is perhaps particularly important in a societal context where national history is controversially uncontroversial and where there is one dominant way of rendering it. How we may come to foster such historical consciousness remains to be shown by research, but the results presented here may offer one piece to this puzzle. After all, we do have to present narratives in history education, and what is most crucial is maybe not the content of these narratives, but rather whether those who deliver them are aware of the contextual contingencies that affect not only the narratives they deliver, but also how they view and deliver them. Without this awareness, national history in Sweden indeed runs the risk of being controversially uncontroversial. 


\section{About the authors}

Robert Thorp is senior lecturer of history education at Uppsala University. He has mainly done research on history educational theory, textbooks, popular history magazines, and history teachers' understanding of history with a particular focus on Cold War history.

Institutional affiliation: Department of Education, Uppsala University, SE-750 02 Uppsala, Sweden.

E-mail: robert.thorp@edu.uu.se

Monika Vinterek is professor of educational work at Dalarna University, Sweden. Her main research interests are general questions of teaching and learning in preschool, primary and secondary education; didactics, instruction, reading practices, history education and history pedagogy.

Institutional affiliation: Department of Educational Science, Dalarna University, SE-791 88 Falun, Sweden.

E-mail: $\underline{\text { mvn@du.se }}$

\section{References}

Ahonen, S. (2014). History education in post-conflict societies. Historical Encounters: A Journal of Historical Consciousness, Historical Cultures, and History Education, 1(1), 75-87.

Akinoglu, O. (2009). Functions of History Education: History Teacher Trainees' Perspective. Education, 129(3), 459-466.

Alvén, F. (2017). Tänka rätt och tycka lämpligt: Historieämnet i skärningspunkten mellan att fostra kulturbärare och förbereda kulturbyggare [To reason correctly and think appropriately: The History subject at the intersection of fostering bearers of culture and preparing builders of culture]. Malmö universitet.

Andolf, G. (1972). Historien på gymnasiet: Undervisning och läroböcker 1820-1965 [History at Upper Secondary School: Teaching and textbooks 1820-1965]. Esselte Studium.

Angier, K. (2017). In search of historical consciousness: An investigation into young South Africans' knowledge and understanding of 'their' national histories. London Review of Education, 15(2), 155-173. https://doi.org/10.18546/LRE.15.2.03

Ankersmit, F. (2013). Representation as a Cognitive Instrument. History \& Theory, 52(2), 171-193.

Bentrovato, D., Korostelina, K. V., \& Schulze, M. (2016). History Can Bite: History Education in Divided and Post-War Societies. GV\&R unipress.

Carretero, M., Rodríguez-Moneo, M., \& Asensio, M. (2012). History Education and the Construction of a National Identity. In M. Carretero, M. Asensio, \& M. Rodríguez-Moneo (Eds.), History Education and the Construction of National Identities (pp. 1-16). Information Age Pub.

Chinnery, A. (2019). The bearing of historical consciousness. Historical Encounters: A Journal of Historical Consciousness, Historical Cultures, and History Education, 6(1), 96-109. 
Danielsson Malmros, I. (2012). Det var en gång ett land... Berättelser om svenskhet i historieläroböcker och elevers föreställningsvärldar [There once was a country... Tales of Swedishness in history textbooks and students' minds]. Agering.

Gadamer, H.-G. (1975). The Problem of Historical Consciousness. Graduate Faculty Philosophy Journal, 5(1), 8-52.

Goldberg, T. (2017). The useful past in negotiation: Adolescents' use of history in negotiation of inter-group conflict. London Review of Education, 15(2), 194-211. https://doi.org/10.18546/LRE.15.2.05

Indzic Dujso, A. (2015). Nationella minoriteter i historieundervisningen: Bilder av romer $i$ Utbildningsradions program under perioden 1975-2013 [National minorities in history education: Portrayals of Roma in Utbildningsradion’s publications between 1975 and 2013]. Umeå universitet.

Jeismann, K.-E. (1979). Geschichtsbewußtsein [Historical consciousness]. In K. Bergmann, A. Kuhn, J. Rüsen, \& G. Schneider (Eds.), Handbuch der Geschichtsdidaktik [Handbook of history didactics] (1st ed., Vols 1-1, pp. 42-45). Pädagogischer Verlag Schwann.

Karlsson, K.-G. (2014). Historia, historiedidaktik och historiekultur-Teori och perspektiv [History, history didactics, and historical culture]. In K.-G. Karlsson \& U. Zander (Eds.), Historien är närvarande: Historiedidaktik som teori och tillämpning [The presence of history: History didactics as theory and application] (pp. 13-89). Studentlitteratur.

Létourneau, J. (2008). Transmettre la culture comme mémoire et identité: Au cœur du débat sur l'éducation historique des jeunes québécois [To transform culture as memory and identity: the centre of the debate on the history education of young Québeckers]. Revue française de pédagogie. Recherches en éducation, 165(4), 43-54.

Létourneau, J., \& Chapman, A. (2017). Negotiating the nation: Young people, national narratives and history education. London Review of Education, 15(2), 149-151. https://doi.org/10.18546/LRE.15.2.01

Lévesque, S. (2017). History as a 'GPS': On the uses of historical narrative for French Canadian students' life orientation and identity. London Review of Education, 15(2), 227242. https://doi.org/10.18546/LRE.15.2.07

Lilliestam, A.-L. (2015). Nyblivna lärarstudenters syn på historia och historieundervisning [Teacher students' views on history and history education]. Nordidactica: Journal of Humanities and Social Science Education, 5(4), 21-47.

Linderborg, Å. (2001). Socialdemokraterna skriver historia: Historieskrivning som ideologisk maktresurs 1892-2000 [The Social Democrats write history: Historiography as an ideological resource of power]. Atlas.

Lindmark, D., \& Sundström, O. (2017). Samerna och Svenska kyrkan: Underlag för kyrkligt försoningsarbete [The Sámi and the Swedish church: A basis for ecclesiastical reconciliation]. Gidlunds förlag.

Löfström, J. (2012). I skuggan av historiska orättvisor? Vad finländska gymnasieelevers reflektioner kring historiska gottgörelser berättar om deras historiemedvetande [In the shadow of historical injustices: What Finnish upper secondary school students' reflections on historical redress can tell us of their historical consciousness]. In P. Eliasson, K. Hammarlund, E. Lund, \& C. T. Nielsen (Eds.), Historiedidaktik i Norden 9 [History didactics in Scandinavia 9] (pp. 74-95). Malmö högskola; Högskolan i Halmstad.

Lozic, V. (2010). I historiekanons skugga: Historieämne och identifikationsformering i 2000talets mångkulturella samhälle [In the shadow of the historical canon: The history subject and identity construction]. Malmö högskola.

Ludvigsson, D. (2011). Lärarstudenters relation till historieämnet [Teacher students' relations to the history subject]. Nordidactica: Journal of Humanities and Social Science Education, 1(1), 40-57. 
Lyotard, J.-F. (1984). The Postmodern Condition: A Report on Knowledge. Manchester University Press.

Macintyre, S., \& Clark, A. (2004). The History Wars. Melbourne University Press.

Nolgård, O., \& Nygren, T. (2019). Considering the past and present of Romani in Sweden: Secondary school pupils' thinking and caring about the history of the Romani in national tests. Education Inquiry, 10(4), 344-367. https://doi.org/10.1080/20004508.2019.1607708

Nordgren, K. (2016). How to Do Things With History: Use of History as a Link Between Historical Consciousness and Historical Culture. Theory \& Research in Social Education, 44(4), 479-504. https://doi.org/10.1080/00933104.2016.1211046

Nygren, T. (2011). History in the Service of Mankind: International Guidelines and History Education in Upper Secondary Schools in Sweden, 1927-2002. Umeå universitet.

Olofsson, H., Samuelsson, J., Stolare, M., \& Wendell, J. (2017). The Swedes and Their History. London Review of Education, 15(2), 243-258.

Parkes, R. J. (2011). Interrupting History: Rethinking History Curriculum after 'The End of History'. Peter Lang Publishing.

Persson, A. (2016). Mormor, oönskade tyskar och en hänsynslös dansk: Några reflektioner om identifikation och mening, efter en kritisk läsning av en nyutgiven lärobok i historia för den svenska grundskolans mellanår [Grandmother, unwanted Germans and a ruthless Dane: Some reflections on identification and meaning after a critical reading of a recently published history textbook for primary school]. In U. Claesson \& D. Åhman (Eds.), Kulturell reproduktion i skola och nation: En vänbok till Lars Petterson [Cultural reproduction in school and nation: Studies in honour of Lars Petterson] (pp. 251-268). Gidlunds förlag.

Porat, D. A. (2004). It's Not Written Here, but This Is What Happened: Students' Cultural Comprehension of Textbook Narratives on the Israeli-Arab Conflict. American Educational Research Journal, 41(4), 963-996.

Runcis, M. (1998). Steriliseringar i folkhemmet [Sterilisations in the Welfare State]. Stockholms universitet.

Rüsen, J. (2012). Tradition: A Principle of Historical Sense-Generation and Its Logic and Effect in Historical Culture. History and Theory, 51(4), 45-59.

Samuelsson, J. (2017). History Wars in Sweden? Historical Encounters: A Journal of Historical Consciousness, Historical Cultures, and History Education, 4(2), 30-47.

Seixas, P. (2000). Schweigen! Die Kinder! Or, Does Postmodern History Have a Place in the Schools? In P. N. Stearns, P. Seixas, \& S. Wineburg (Eds.), Knowing, Teaching, and Learning History: National and International Perspectives (pp. 19-37). New York University Press.

Serrano, J. S., \& López Facal, R. (2016). Narrativas nacionales históricas de estudiantes y profesorado en formación [The National Historical Narratives of Students and Trainee Teachers]. Revista de Educación, 374(5), 118-141. https://doi.org/10.4438/1988-592X$\underline{\mathrm{RE}-2016-374-328}$

Spjut, L. (2018). Att (ut)bilda ett folk: Nationell och etnisk gemenskap i Sveriges och Finlands svenskspråkiga läroböcker för folk- och grundskola åren 1866-2016 [To educate a people: National and ethnic companionship in Swedish and Finnish Swedish-speaking textbooks for primary school between 1866 and 2016]. Örebro universitet.

Thorp, R. (2015). Popular history magazines and history education. Historical Encounters: A Journal of Historical Consciousness, Historical Cultures, and History Education, 2(1), $102-112$.

Thorp, R. (2016). Uses of history in history education. Umeå universitet. 
Thorp, R. (2017). Experiencing, using, and teaching history: Aspects of two history teachers' relations to history and educational media. Journal of Educational Media, Memory, and Society, 9(2), 129-146.

VanSledright, B., \& Reddy, K. (2014). Changing epistemic beliefs? An exploratory study of cognition among prospective history teacher. Tempo e Argumento, 6(11), 28-68.

Vinterek, M., Donnelly, D., \& Thorp, R. (2017). Tell us about your nation’s past: Swedish and Australian pre-service history teachers' conceptualisation of their national history. International Journal of Research on History Didactics, History Education, and History Culture, 38, 51-72.

Wansink, B. G. J., Akkerman, S. F., Vermunt, J. D., Haenen, J. P. P., \& Wubbels, T. (2017). Epistemological tensions in prospective Dutch history teachers' beliefs about the objectives of secondary education. The Journal of Social Studies Research, 41(1), 11-24. https://doi.org/10.1016/j.jssr.2015.10.003

Wassermann, J., \& Bentrovato, D. (2018). Confronting controversial issues in history classrooms: An analysis of pre-service high school teachers' experiences in post-apartheid South Africa. Yesterday and Today, (20), 72-90. https://doi.org/10.17159/22230386/2018/n19a4

Zander, U. (2001). Fornstora dagar, moderna tider: Bruk av och debatter om svensk historia från sekelskifte till sekelskifte [Glorious days, modern times: Uses of and debates on Swedish history from turn of centuries to turn of centuries]. Nordic Academic Press.

Åström Elmersjö, H. (2013). Norden, nationen och historien: Perspektiv på föreningarna Nordens historieläroboksrevision 1919-1972 [Scandinavia, the nation and history: Perspectives on The Norden Association's history textbook revision 1919-1972]. Nordic Academic Press.

Åström Elmersjö, H., Clark, A., \& Vinterek, M. (Eds.) (2017). International Perspectives on Teaching Rival Histories: Pedagogical Responses to Contested Narratives and the History Wars ( $1^{\text {st }}$ ed.). Palgrave Macmillan. 